\title{
KONSEP DAKWAH PERSPEKTIF ULAMA BETAWI
}

\author{
Zakaria \\ UIN Syarif Hidayatullah Jakarta \\ zakaria@uinjkt.ac.id
}

\begin{abstract}
Abstraks: Dakwah yang dikembangkan ulama Betawi melalui tiga bentuk, yaitu bi al-lisan, bi al-qolam dan bi al-hal. Jaringan intelektual ulama Betawi terkoneksi dengan jaringan enam guru utama ulama Betawi yaitu Guru Marzuqi, Guru Mansyur, Guru Mugni, Guru Madjid, Guru Romli dan Guru Kholid. Melalui jalur keenam guru utama ini, ulama Betawi sanad keilmuannya terkoneksi dengan ulama di Timur Tengah. Konsep dakwah yang dirumuskan ulama Betawi adalah dakwah yang berlandaskan akidah ahlu al-sunah wa al-jamaah, bertasawuf al-Ghazali dan bermazhab Imam Syafii.

Fokus analisis penelitian ini berdasarkan tiga hal, yaitu bagaimana konsep dakwah perspektif ulama Betawi, Apakah jaringan inteletual ulama betawi memiliki sanad keilmuan dengan ulama Timur Tengah?, Apa Konsep dakwah yang diterapkan oleh ulama Betawi?. Pendekatan yang digunakan adalah kualitatif dengan analisis deskriptif melalui tiga tahap pengumpulan data, yaitu wawancara, dokumentasi dan observasi. Subyek penelitiannya adalah KH. Abdullah Syafii di Perguruan Asy Syafiiyah Jakarta dan KH. Abdurrahman Nawi di Depok. Sebagai pisau analisis adalah teori jaringan ulama azyumardi Azra dan sistem dakwah Amrullah Achmad.
\end{abstract}

Kata kunci: Jaringan Intelektual, Ulama Betawi, Konsep Dakwah.

\section{Permalink/DOI: http://doi.org/10.15408/dakwah}

\section{Pendahuluan}

Penduduk asli jakarta dikenal sebagai etnis Betawi adalah masyarakat yang relegius, egaliter dan multikultural. Relegiousitas etnis betawi berhubungan erat dengan sejarah perkembangan Islam di Jakarta dan konsep dakwah yang dikembangkan oleh ulama ulama betawi. Islam bagi etnis Betawi bukan hanya sekedar agama, tetapi sebagai pembentuk identitas dan kebudayaan. Semua tradisi dan kebudayaan yang dikembangkan oleh etnis Betawi selalu didasari atas nilainilai

Islam.

Nilai-nilai Islam yang rahmah li al-alamin membentuk etnis Betawi menjadi masyarakat yang egaliter dan sangat terbuka. Semua orang di hadapan etnis Betawi memiliki kedudukan yang sama, tidak ada system kelas. Kemuliaan seseorang dinilai dari ketinggian derajat ilmunya. Dalam konteks inilah ulama menempati posisi yang tinggi di mata etnis Betawi, bukan pengusaha atau penguasa. Pembentukkan identitas Etnis Betawi yang islami adalah buah dari perjuangan para 
Ulama di Tanah Betawi. ${ }^{2}$ Di antara deretan ulama kenamaan Betawi yang berpengaruh adalah KH. Abdullah Syafii dan KH. Abdurrahman Nawi.

\section{Biografi Singkat Narasumber. KH. Abdullah Syafi'ie}

KH. Abdullah Syafi'ie lahir di kampung Balimatraman Jakarta Selatan pada tanggal 16 Syaban 1329 H/ 10 Agustus 1910 Hari Sabtu dan wafat pada tanggal 3 September 1985. Nama ayahnya H. Syafi'ie bin Sairan dan ibundanya Nona binti Asy'ari. Mempunyai dua orang adik perempuan yang bernama Hj. Siti Roqayah dan Hj. Siti Aminah.3Kedua orang tuanya cinta kepada orang orang alim dan soleh sehingga dari sejak kecil sudah diarahkan untuk belajar ilmu agama.Sambil belajar, menuntut ilmu terus mengajar. Dan pada umur 17 tahun sudah memperoleh surat pemberian tahoe boleh mengajar di langgar partikulir. Ketika berumur 21 tahun mendapat sertifikat dari Rachen Schaf Pemerintah Hindia Belanda bahwa beliau sudah layak menjadi pendidik.4 Pada umur 23 tahun mulai membangun Masjid Al-Barkah di Kampung Balimatraman. Distulah al marhum lebih menekuni pembinaan masyarakat mengajak mereka ke jalan Allah.

Sekitar tahun tigapuluhan dakwahnya lebih meluas lagi mencapai daerah sekitar jakarta dan Almarhum menuntut ilmu ke Bogor (Habib Alwi Bin Thohir Al-Haddad). Pada tahun empat puluhan membangun tempat pendidikan yaitu madrasah tingkat ibtidaiyah dan secara sederhana mulai menampung pelajar-pelajar yang mukim terutama dari keluarga. Dan tahun 1957 membangun aula Asy Syafiiyah yang diperuntukkan bagi nadrasah tingkat tsanawiyah Lilmuballighin wa al-Muallimin. Tahun 1965 mendirikan akademi Pendidikan Islam Asy Syafiiyah (AKPI Asy Syafiiyah). Tahun 1967 Mendirikan Stasiun Radio Asy Syafiiyah. Tahun 1969 AKPI ditingkatkan menjadi Universitas Islam Asy Syafiiyah. Tahun 1968 merintis tempat pendidikan di suatu desa pinggiran Jakarta yaitu Jatiwaringin Kecamatan Pondok Gede Bekasi sebagai pengembangan pendidikan yang telah ada. Tahun 1974-1975 membangun pesantren putra dan pesantren putri di Jatiwaringin. Pada tahun 1978 membangun pesantren Khusus untuk yatama dan masakin.

Pengembangan sarana untuk pendidikan dan pesantren terus dikembangkan ke daerah sekitar Jakarta, seperti di Cilangkap Pasar Rebo, di Payangan Bekasi, Kampung Jakasampurna Bekasi dan lain lain. Tahun 1980 mulai menyiapkan lokasi untuk Universitas Islam Asy Syafiiyah di Jatiwaringin.

\section{KH. Abdurrahman Nawi}

KH. Abdurrahman Nawi lahir di Tebet Jakarta pada hari Jumat bulan Safar tahun $1354 \mathrm{H}$ (1933 M). Ayahnya bernama H. Nawi bin Sueb dan ibunya bernama Hj. Ainin binti H. Rudin. Saat ini Buya tinggal di pesantren Al-Awwabin Jl. Sawangan Raya No. 21 Pancoran Mas Depok Jawa Barat.

Sejak kecil Buya telah dididik oleh ayahnya cinta kepada ilmu agama. Di antara ulama yang menjadi gurunya adalah KH. Siman (Tebet), KH. Ghozali, KH. Moh. Natsir, KH. Mohammad Zein bin H. Said, KH. Muhammad Yunus, KH. Ahmad Junaidi, KH. Mahmud, KH. Abdullah Syafi'ie, Ustadz Hadi Jawas dan Syekh Abdullah Arfan. Guru-gurunya dari kalangan habaib adalah Habib Ali Bin Husein Alattas, mengambil barokah dari Habib Muhamad Alwi al-Maliki dan Habib Zein 
bin Smith. Saat menunaikan ibadah haji sempat belajar kepada Syeikh Abdul Kadir Mandailing dan Syeikh Husein al-Fatani. 5

Berbekal ilmu yang diperolehnya dari para guru dan habaib, Buya mulai merintis pengajian di rumahnya dengan nama majlis ta'lim Assalafiyah. Pada tahun 1976 mulai membangun gedung madrasah dua lantai dan rampung pada tahun 1979 diresmikan oleh KH. Idham Khalid yang mengganti nama Assalafiyah menjadi Al-Awwabin. Karena peserta didik semakin banyak dan sudah tidak lagi mampu menampung murid, pada tahung 1982 didirikan pesantren $\mathrm{Al}$ Awwabin di Sawangan Depok diresmikan oleh Mentri Agama ketika itu Munawir Syadzali. Saat ini pesantren Al Awwabin telah dibuka pula di Bedahan Sawangan Depok khusus untuk santri putri. Untuk meluaskan jangkauan dakwah sudah didirikan Radio Dakwah Al-Awwabin yaitu Rida 98,5 FM. ${ }^{6}$

\section{Pembahasan}

\section{Jaringan Intelektual Ulama Betawi.}

Ridwan Saidi mengartikan ulama Betawi sebagai ulama yang berasal dari wilayah kebudayaan Betawi, meliputi wilayah Jakarta, Bekasi, Kerawang, Depok, Bogor, Tanggerang dan Kepulauan Seribu. Keulamaannya membentuk sentra-sentra intelektual Islam di Betawi. Secara nasab (garis keturunan) ulama Betawi bukan berasal dari kalangan habib dan sayyid.7

Prof. Azyumardi Azra,Ph.D, Mphil memandang bahwa pengertian ulama Betawi masih menggunakan definisi konvensional, yaitu: "Ulama adalah mereka yang belajar ilmu-ilmu keagamaan Islam, apakah secara langsung kepada ulama tertentu atau dalam lembaga-lembaga pendidikan tradisional Islam seperti halaqah, madrasah dan bahkan juga pesantren. Mereka yang kemudian memiliki pengetahuan cukup memadai dan bahkan ahli dalam ilmu-ilmu keagamaan Islam seperti fiqh, tafsir, atau tasawuf dan selanjutnya mengabdikan dirinya dalam masyarakat muslim, yang kemudian mengakui mereka sebagai ulama”. 8

Prof. Dr. Murodi, MA menjelaskan bahwa orang Betawi memberi gelar Mu'allim adalah gelar kehormatan untuk para guru agama yang memiliki pengetahuan agama yang cukup luas. Istilah lain yang dipakai adalah tuan guru. Perbedaan dua istilah tersebut dilatar belakangi oleh luas dan dalam ilmu pengetahuan agama yang dimiliki dan besar kecil lembaga pendidikan dan jumlah murid yang dibimbingnya.Sebahagian besar ulama Betawi memiliki jaringan kuat dengan ulama Jawa, Sumatra dan Haramain. ${ }^{9}$ Ulama Betawi adalah orang-orang yang memiliki pengetahuan luas, berasal dari wilayah kebudayaan Betawi, penduduk asli Jakarta bukan keturunan Habib atau Sayid, memiliki jaringan keulamaan dengan ulama Jawa, Sumatera dan Timur Tengah.

Prof. Dr. Murodi, MA menjelaskan bahwa orang Betawi memberi gelar Mu'allim adalah gelar kehormatan untuk para guru agama yang memiliki pengetahuan agama yang cukup luas. Istilah lain yang dipakai adalah tuan guru. Perbedaan dua istilah tersebut dilatar belakangi oleh luas dan dalam ilmu pengetahuan agama yang dimiliki dan besar kecil lembaga pendidikan dan jumlah murid yang dibimbingnya.Sebahagian besar ulama Betawi memiliki jaringan kuat dengan ulama Jawa, Sumatra dan Haramain. ${ }^{10}$ Ulama Betawi adalah orang-orang yang memiliki pengetahuan luas, berasal dari wilayah kebudayaan Betawi, penduduk asli Jakarta bukan keturunan Habib atau Sayid, memiliki jaringan keulamaan dengan ulama Jawa, Sumatera dan Timur Tengah

Azyumardi Azra menjelaskan secara gamblang tentang genealogi Ulama timur Tengan dan Kepulauan Nusantara abad ke XVII dan abad ke XVIII. Abad ke XVII ulama nusantara yang 
membentuk jaringan dan terhubung dengan ulama Timur Tengah adalah Nur al-Din al-Raniri (w. 1068/1658), Abd al-Rauf al-Sinkili (1024-1105/1615-1693), dan Muhamad Yusuf al-Makassari (1037-1111/1627-1699). Sedangkan poros ulama Nusantara abad ke XVIII adalah Abd al-Shamad al-Palimbani, Muhamad Arsyad al-Banjari dan Dawud Bin Ab dullah al-Fattani.

Meneruskan temuan Azyumardi Azra tentang jaringan Ulama Timur Tengah dan Kepulauan Nusantara, Rakhmad Zailani Kiki melaui penelitiannya menjelaskan bahwa jaringan ulama Timur Tengah sebagaimana tersambung dengan jaringan ulama Nusantara, hal yang sama juga terjadi di Tanah Betawi. Ulama- ulama Betawi secara interen membentuk jaringan keulamaan, dengan ulama Timur Tengah juga membangun jaringan keulamaan.

Terdapat enam poros utama ulama Betawi yang membentuk jaringan keulamaan, yaitu Guru Manshur Jembatan Lima, Guru marzuki Cipinang Muara, Guru Mughni Kuningan, Guru Madjid Pekojan, Guru Khalid Gondangdia dan Guru Mahmud Ramli Paseban.

Guru pertama Guru Manshur adalah ayahnya sendiri KH. Abdul Hamid. Setelah ayahnya wafat ia mengaji kepada kakak kandungnya KH. Mahbub Bin Abdul Hamid dan kakak misannya KH. Thabrani Bin Abdul Mughni dan kepada Syaikh Mujtaba. Ulama terkemuka di Mekah yang menjadi gurunya adalah Syekh Mukhtar Atharid al-Bogori, Syekh Umar Bajunaid al-Hadrami, Syekh Ali Al-Maliki, Syekh Said al-Yamani, Syekh Umar Sumbawa dan Syekh Mujtaba. Khusus untu ilmu falak ia belajar kepada Abdurrahman Misri asal Mesir dan Ulugh Bek ulama Samarkhand. Ulama Ulama Betawi yang menjadi muridnya adalah Muallim Roji'un Pekojan, KH. Muhadjirin Amsar Ad Dary, Muallim Rasyid dan Muallim KH. M. Syafi’i Hadzami. ${ }^{11}$

Guru utama Guru Marzuki di Betawi adalah Ustadz H. Anwar, Guru Bakir, Sayyid Usman Bin Muhamad Banahasan. Sedangkan guru-gurunya di Mekah adalah Syaikh Usman Sarawak, Syaikh Muhamad Ali al-Maliki, Syaikh Umar Bajunaid al-Hadrami, Syaikh Muhamad Amin Sayid Ahmad Ridwan, Syaikh Syaikh Hasbuloh al-Mishri, Syaikh Umar al-Sumbawi, Syaikh Mukhtar Atharid, Syaikh Ahmad Khatib al-Minangkabawi, Syaikh Mahfuz at Tarmisi, Syaikh Said alYamani, Syaikh Abdul Karim Ad-dagestani dan Syaikh Muhamad Umar Syatho. Khusus dari gurunya Syaikh Sayyid Ahmad Zaini Dahlan Guru Marzuki menerima ijazah untuk menyebarkan tarekat Alawiyin. ${ }^{12}$

KH. Marzuki mendapat julukan Guru Ulama Betawi. Julukan tersebut menjadi nyata karena banyak di antara murid muridnya yang menjadi ulama besar di Betawi. Setidaknya ada empat puluh satu ulama terkemuka yang pernah belajar kepadanya, yaitu Muallim Thabrani Paseban, KH. Abdullah Syafi'ie (Pendiri Perguruan Asy Syafiiyah), KH. Thohir Rohili (Pendiri Perguruan Ath Thahiriyah), KH. Noer Ali (Pendiri Perguruan At Taqwa Bekasi), KH. Achmad mursyidi (Pendiri Perguruan Al-Falah), KH. Hasbiyallah (Pendiri Peguruan Al-Wathoniyah), KH. Ahmad Zayadi Muhadjir (Pendiri Perguruan Az Ziyadah), Guru asmat Cakung, KH. Mahmud (Pendiri Perguruan Al Mamur), Kh. Muchtar Thabrani (Pendiri YPI An Nur Bekasi), KH. Chalid Damat (Pendiri Perguruan Al-Khalidiyah), dan KH. Ali Syibromalisi (Pendiri Perguruan Darussaadah Jakarta). ${ }^{13}$

Guru pertama guru Mughni adalah ayahnya sendiri H. Sanusi dan belajar mengaji kepada H. Jabir. Dan selama belajar di Mekah ulama yang menjadi gurunya adalah Syaikh Said al-Babsor, Syaikh Abdul karim al-Dagestani, Syaikh Muhamad Said al- Yamani, Syaikh Umar bin Abi Bakar al-Bajnid, Syaikh Muhamad Ali Al-Maliki, Syaikh Ahmad al-Dimyathi, Syaikh Sayid Muhamad 47-55 
Hamid, Syaikh Abdul Hamid al-Qudsi, Syaikh Muhamad Mahfuz al-Teramasi, Syaikh Muhamad Mukhtar At Tharid al-Bogori, Syekh Said Utsman, Syaikh Muhamad Umar Syatho, Syaikh Sholeh Bafadol, Syaikh Achmad Khatib al-Minangkabawi, dan Syaikh Nawawi al-Bantani. Murid-murid Guru Mugni yang menjadi ulama besar adalah Guru Naim Cipete, Guru Amin Kali Bata dan Syaikh Dr. Nachrawi Abdussalam. ${ }^{14}$

Guru Majid belajar agama kepada ayahnya KH. Abdurrahman dan di Mekah ia sempat belajar kepada Syaikh Mukhtar Atharid dan Syaikh Said al-Yamani. Murid muridnya yang menjadi ulama di Betawi adalah Muallim Thabrani Paseban, KH. Abdul Ghani Basmol, Kh. Abdul Razak Mamun Tegal Parang, KH. Abdul Rahman Petunduan, KH. Sholeh Koja, KH. Abdullah Syafii, KH. Nahrawi Kuningan, KH. Saidi Ciputat, KH. Muhamad Muhadjirin Amsar Ad Dari Bekasi, KH. Najib Tanah Abang, KH. Bakir Rawabangke, KH. Abdurrahman Bekasi, KH. Bakar Tambun, KH. Abdullah Cakung, KH. Mukhtar Cengkareng, KH. Thohir Rohili Kampung melayu, KH. Thohir Kebayoran dan lain lain. ${ }^{15}$

Guru Khalid Gondangdia pernah belajar di Mekah selama sebelas tahun. Diantara guru gurunya di Mekah adalah Syaikh Mukhtar At Tharid dan Syaikh Umar Bajunaid. Murid muridnya yang menjadi ulama adalah Guru Yakub Kebon Sirih, Guru ilyas Cikini, Guru Mujib Tanah Abang, Guru Rahab Citayam, KH. Ma'mun Rawa Belong, KH. Mukhtar Sidik Kemayoran, KH. Abdurrahman Bojong Gede, dan KH. Yahya Suhaimi yang diangkat menjadi menantunya. ${ }^{16}$

Tidak banyak catatan tentang riwayat hidup guru Romli, ia bersama orang tua dan ketiga saudaranya berangkat ke Mekah. Selama tujuh belas tahun tinggal di Mekah mengembara untuk mempertahankan hidup. Di antara murid muridnya yang menjadi ulama adalah KH. Muhamad, Guru Asmat Cakung Barat, Mu’allim Syafri kemayoran dan Muallim Syafi'i Hadzami. ${ }^{17}$ Secara jaringan keulamaan, kedua ulama Betawi tersebut terhubung dengan KH. Marzuki Cipinang Muara.

KH. Abdullah Syafi'ie termasuk dalam sentra intelektual ulama Betawi pasca kemerdekaan sampai orde baru untuk daerah Bali Matraman. Dan Buya KH. Abdurrahman Nawi adalah ulama yang termasuk sentra intelektual ulama Betawi di era reformasi sampai sekarang untuk daerah Tebet Jakarta Selatan. Pendidikan KH. Abdullah Syafii dimulai dengan memasuki Sekolah Rakyat (SR) hanya selama dua tahun. Sejak belia beliau suka melakukan rihlah secara ilmiah, oleh karena itu dari ustadz ke ustadz dari habib ke habib adalah kegemarannya dalam menuntut ilmu. Di antara ulama Betawi yang pernah didatanginya untuk menimba ilmu adalah Muallim Mushonnif darinya beliau belajar ilmu nahwu; KH. Abdul Madjid untuk belajar ilmu fiqih; KH. Marzuki menimba ilmu fiqih; Habib Alwi Al-Haddad menyerap ilmu tasawuf, tafsir dan retorika; Habib Salim Bin Jindan Jatinegara dalam bidang ilmu hadits; Guru Mansur dalam bidang ilmu falaq; dan Habib Ali Al-Habsyi Kwitang. Saat menimba ilmu kepada Habib Ali Al-Habsyi Kwitang, bersama dengan KH. Fathullah Harun, KH. Thohir Rohili dipersaudarakan dengan putra Habib Ali AlHabsyi yaitu Habib Muhammad Al-Habsy. Dalam perkembangan selanjutnya, KH. Abdullah Syafii mendirikan Perguruan Asy Syafiiyah Jakarta, KH. Thohir Rohili mendirikan Perguruan Ath Thohiriyah Jakarta, sedangkan KH. Fathullah Harun menjadi ulama Betawi yang Mashur di Malaysia dan menjadi imam besar di Masjid Negara Kuala lumpur. ${ }^{18}$

Berdasarkan rihlah ilmiah yang dilakukan oleh KH. Abdullah Syafi'ie terdapat enam guru utamanya yaitu KH. Abdul Madjid, KH. Marzuki, Habib Alwi Al-Haddad, Habib Salim Bin Jindan, 
Guru Manshur dan Habib Ali al-Habsyi. Melaui keenam guru utama inilah KH. Abdullah Syafi'ie menyerap berbagai disiplin keilmuan sperti ilmu fiqih, ilmu tasawuf, ilmu tafsir, ilmu hadits, ilmu falaq dan ilmu khitobah (retorika). Sebagaimana keenam guru utama tersebut, beraqidah Ahlussunah wal Al-jamaah, berfiqih Imama Syafi'ie dan bertasawuf al-Ghazali, maka apa yang disampaiakan oleh guru gurunya, begitu pula apa yang disampaiakan dan dikembangkan oleh $\mathrm{KH}$. Abdullah Syafi'ie dalam berdakwah. Sederhananya konsep dakwah yang dikembangkan oleh KH. Abdullah Syafi'ie menerapkan apa yang diajarkan dan mengembangkan konsep dakwah yang dicontohkan oleh guru-gurunya.

Ketekunan KH. Abdullah Syafi'ie dalam menanamkan ilmu kepada murid-muridnya membuahkan hasil dengan melahirkan ulama ulama ternama di Betawi. Di antara murid muridnya adalah buya KH. Abdurrahman Nawi pendiri Pondok Pesantren Al-Awwabin Depok, Syaikh KH. Saifuddin Amsir Kali Malang, KH. Abdul Rasyid Putranya dan pendiri Pesantren Al-Quran Pulo Air Sukabumi, Hj. Tuty Alawiyah putrinya ketua BKMT dan pernah menjadi Mentri Peranan Wanita, KH. Rahmat Abdullah seorang Murobi dan KH. Ahmad Syanwani Tanah sereal Bogor. ${ }^{19}$

\section{Konsep Dakwah dan Penerapannya.}

Berdasarkan pamflet biografi singkat KH. Abdullah Syafii yang dibagikan saat peringatan haulnya yang ke 31 di masjid al-Barkah Bali Matraman Jakarta Selatan 4 September 2016 , yang dibacakan oleh KH Abdul Rasyid Abdullah Syafii tergambar dengan jelas konsep dakwah yang dikembangkan oleh ulama Betawi tersebut. KH. Abdullah Syafi'ie senantiasa menyerukan umat kepada Tauhid Allah dan aqidah ahl al-Sunnah wa al- Jamaah. Setiap kali berceramah mengajak umat membaca istigfar dan kalimah al-thoyyibah Laa Ilaaha Illa Allah Muhamad al-Rasulullah. ${ }^{20}$

Tauhid Allah adalah konsep mengesakan Allah, menempatkan Allah sebagai Dzat yang Tunggal, tidak ada Tuhan selain Allah, tidak ada sekutu baginya dan tidak ada yang melebihi diriNya. Dasar dari tauhid Allah adalah keimanan, yaitu dimensi paling asas dalam ajaran Islam di samping islam dan ihsan. Untuk menanamkan Tauhid Allah disamping melantunkan kalimah Thoyyibah Laa Ilaaha Illallah di setiap ceramahnya, Al maghfurlah KH. Abdullah Syafi'ie meminta semua santrinya mendawamkan bacaan aqidah karya Habib Alwi al-Haddad. Sampai saat ini, melantunkan kalimah Thoyyibah masih terus dilestarikan saat pengajian minggu pagi di majlis ta'lim Masjid Al-Barkah oleh KH. Abdul Rasyid Abdullah Syafi'ie. Sedangkan pembacaan Aqidah dilakukan setelah pemabacaan maulid Simtud Durror, yang memimpin bacaan Aqidah adalah cucu KH. Abdullah Syafi'ie, Yaitu Ust. H. Muhamad Fathullah bin KH. Abdul Rasyid.

KH. Abdurrahman Nawi adalah murid terbaik KH. Abdullah Syafii yang Selain KH. Abdul Rasyid murid KH. Abdullah Syafi'ie yang meneruskan konsep dakwahnya adalah Buya KH. Abdurrahman Nawi pendiri dan pengasuh Pondok Pesantren Al-Awwabin. Hal ini berdasarkan hasil wawancara peneliti dengan putra Buya KH. Abdurrahman Nawi yaitu KH. Ahmad Muhtar yang merupakan pimpinan Pondok Pesantren Al-Awwabin Depok.

Sebagai seorang Ulama dari Tanah Betawi, Dalam berceramah Buya menggunakan bahasa Betawi yang kental, ceplak-ceplok, tapi kena dan yang mendengarnya merasa senang dan tidak tersinggung. Isi ceramah Buya berisi tuntunan nilai berlandaskan Aqidah Ahlussunah wa alJamaah. Materi dakwah yang biasa Buya sampaikan adalah masalah masalah ibadah, akhlak, aqidan dan sejarah. Buah karya tulis Buya yang dipakai di pesantren dan masyarakat sampai saat 
ini adalah adalah Sulamul Ibad, Nahwu Melayu, Tujuh kaifiyat, manasik Haji dan Mutiara Ramadhan. ${ }^{21}$

Aplikasi konsep dakwah yang dilakukan oleh para ulama Betawi meliputi tiga bentuk dakwah tersebut, bi al-lisan, bi al-qalam dan bi al-hal.

\section{Aplikasi Konsep Dakwah secara Lisan (bi al-lisan).}

Agus Milaz Jamal mendeskripsikan KH. Abdullah Syafi’ie sebagai "Singa Podium Dari Betawi”. Ungkapan ini tidak berlebihan, Karena KH. Abdullah Syafi’ie dalam menyampaikan amar ma'ruf nahyi munkar bersifat langsung terhadap audiens dengan menggunakan lisannya, yang dalam bahasa sekarangh dikenal dengan istilah "orator". Kemampuannya dalam berkomunikasi lisan sangat mengagumkan, ceramah ceramahnya selalu dipenuhi oleh jamaah, baik dalam pengajian rutin minggu pagi di Masjid Al-Barkah Bali Matraman, maupun di masjid, mushalla dan majlis talim yang mengundangnya untuk berceramah. ${ }^{22}$

Pada tahun 1967 untuk meluaskan jangkauan ceramah ceramahnya Kiyai mulai mendirikan radio dakwah asy Syafiiyah. Lewat program yang disebut oleh Kiyai "Jauh di Mata Dekat Di Telinga” kuliah subuh Kiyai setiap pagi disiarkan di radio tersebut. Ceramah ceramah Kiyai di radio Asy Syafiiyah disenangi oleh, khususnya masyarakat Jakarta, umumnya adalah masyarakat di luar jakarta yang terjangkau oleh pemancar radio tersebut. Sampai saat ini rekaman ceramah ceramah Kiyai masih terdokumentasi dengan baik di Radio Asy Syafiiyah.

Murid KH. Abdullah Syafi'ie yang juga menerapkan konsep dakwah bi al-lisan adalah Buya KH. Abdurrahman. Kepiawaian Buya dalam berceramah mendapat apresiasi dari Hamzah Haz yang saat itu masih menjabat sebagai Wakil Presiden menjuluki KH. Abdurrahman Nawi, Habib Ali Bin Abdurrahman Assegaf dan Habib Husein Bin Ali Al attas sebagai "Tiga Serangkai Ulama Betawi”. Latar belakang pemberian julukan tersebut karena mereka berketiga sering dijumpai oleh Hamzah Haz selalu bersama dalam mengisi acara acara dakwah. Uniknya, setelah pemberian julukkan tersebut ketiganya jadi semakin sering bersama dalam acara acara yang diadakan kalangan habaib, pemerintahan maupun masyarakat umum. ${ }^{23}$

Keahlian Buya KH. Abdurrahman Nawi dalam berceramah sudah terasah dari sebelum pesantren Al-awwabin berdiri. Setiap hari rabu rutin Buya mengisi acara dakwah di Radio Asy Syafiiyah. Setelah pesantren Al-awwabin berdiri Buya menginginkan memiliki radio sendiri, maka berdirilah Radio Dakwah Al-awwabin di daerah Bedahan di pondok pesantren putri Al-awwabin.

Sebelum Pesantren Al Awwabin berdiri, Buya KH. Abdurrahman Nawi biasa setiap Rabu mengisi acara dakwah di Radio Asy Syafiiyah, sudah ribuan rekaman ceramahnya di radio tersebut. Buya menginginkan ceramahnya tidak hanya didengar oleh kalangan terbatas saja, yaitu di masjid dan majlis ta'lim saja, akan tetapi dakwahnya dapat didengar oleh kalangan yang lebih luas atau lintas daerah. Meski tidak secanggih radio Asy Syafiiyah dan At Tahiriyah, maka berdirilah Radio dakwah Al-Awwabin di daerah Bedahan di Pondok Pesantren Putri Al Awwabin. ${ }^{24}$

Baik KH. Abdullah Syafi'ie maupun KH. Abdurrahman Nawi memanfaatkan siaran radio dalam berceramah adalah agar sasaran dakwahnya lebih luas menjangkau audiens yang tidak hanya di mushalla, masjid dan majlis talim saja, melainkan lintas wilayah dan lintas waktu. 


\section{Aplikasi Konsep Dakwah Secara Bi al-Qalam.}

Sejak awal Allah SWT mewajibkan umat Islam untuk membaca dan menulis. Melalui aktivitas membaca dan menulis manusia akan mampu memahami ilmu pengetahuan, baik yang fenomenal maupun yang nomena, baik yang empiris maupun yang intuisi.

"Bacalah dengan (menyebut) nama Tuhanmu yang Menciptakan.Dia telah menciptakan manusia dari segumpal darah. Bacalah, dan Tuhanmulah yang Maha pemurah. yang mengajar (manusia) dengan perantaran kalam. Dia mengajar kepada manusia apa yang tidak diketahuinya." (QS. Al-Alaq (96): 1-5).

Ulama-ulama Betawi di sampiang piawai menyampaikan dakwah secara lisan (Bi al-lisan), mereka juga mahir dalam mengembangkan dakwah lewat tulisan (Bi al-qalam). KH. Abdullah Syafi'ie di sela-sela kesibukannya sebagai penceramah dan pendiri Perguruan Asy Syafiiyah masih sempat menghasilkan karya tulis. ${ }^{25}$ Diantara karya tulis KH. Abdullah Syafi'ie adalah:

a. Al-Muasasat Al-Syafi'iyah Al-Ta'limiyah. Kitab ini memaparkan secara terinci tentang latar belakang didirikannya madrasah dan kurikulum pendidikan yang diajarkan kepada siswanya.

b. Bir Al-Walidain. Buku ini membahas denagn seksama tentang kondisi ibu yang tengah hamil, baik secara fisik maupun psikis, perjuangan yang luar biasa seorang ibu dengan susah payah, berpeluh keringat dan bersimbah darah dengan mempertaruhkan jiwa dan raga. Buku ini juga membahas tentang proses yang harus dilakukan orang tua pasca kelahiran seorang anak, memberikan nama, pemeliharaan dan pengawasan jiwa, pikiran dan perasaannya dengan pendidikan dan pengajaran. Buku itu mengajarkan kepada semua anak agar menghormati, berkhidmat dan berbakti kepada orang tua dalam rangka berbakti kepada Allah dan Rasulnya.

c. Dunia Hanya ada Tiga Golongan. Melalui buku ini KH. Abdullah Syafi'iemengklasifikasikan manusia menjadi tiga kelompok. Pengelompokkan ini berdasarkan nilai yang terkandung dalam Siurat Al-Baqarah ayat 1 sampai 20 . Pertama kelompok manusia yang beriman (mukmin), yaitu manusia yang meyakini Allah mengikut perintah dan menjauhi larangannya ayat 1-5. Kedua, manusia yang ingkar terhadap ajaran Allah (Kafir), yaitu manusia yang tidak percaya Allah serta senantiasa melanggar perintah-Nya ayat 6-7. Ketiga, manusia yang menampilkan sikap yang berbeda antara ucapan dan perbuatannya berbeda (Munafiq) ayat 8-20. Dua manusia yang disebutkan terakhir, kafir dan munafiq adalah manusia yang akan mendapatkan kehinaan dankerugian terutama di akhirat nanti.

d. Mu'jizat Sayiduna Muhammad. Buku ini digunakan oleh KH. Abdullah Syafi'ie untuk menjelaskan mukjizat nabi Muhamad dan nabi-nabi yang lain, sumber datangnya mukjizat, manfaat dan tujuan diturunkannya mukjizat. Kesimpulan akhir dari buku ini adalah mukjizat Nabi Muhamad adalah mukjizat yang paling agung bila dibandingkan dengan mukjizat-mukjizat para nabi.

e. Al-Dinu wa Al-Masjid. Karya ini membahas tentang hubungan anatara agama dan tempat ibadah, pengaruh-pengaruh positif bagi orang yang memakmurkan masjid dan pahala yang besar abagi orang yang memakmurkan masjid 
f. Madarij Al-Fiqh. Dalam bukunya ini, KH. Abdullah Syafi'i menjelaskan esensi agama, Islam, iman dan rukun-rukunnya, pengamalan iman dan Islam termasuk dibahas pula di dalamnya tentang najis dalam kaitannya dengan shalat, qunut dan lainnya. ${ }^{26}$

Buya KH. Abdurrahman Nawi juga konsen dalam mengembangkan dakwah bi al-qalam. Terbukti Buya telah menghasilkan karya ilmiah dalam bentuk buku, yaitu Sulamul Ibad, Nahwu Melayu, Tujuh Kaifiyat, Manasik Haji, Mutiara Ramadhan dan Tuntunan Ziyarah Kubur.

Sebagai seorang Ulama dari Tanah Betawi, Dalam berceramah Buya menggunakan bahasa Betawi yang kental, ceplak-ceplok, tapi kena dan yang mendengarnya merasa senang dan tidak tersinggung. Isi ceramah Buya berisi tuntunan nilai berlandaskan Aqidah Ahlussunah wa alJamaah . Materi dakwah yang biasa Buya sampaikan adalah masalah masalah ibadah, akhlak, aqidan dan sejarah. Buah karya tulis Buya yang dipakai di pesantren dan masyarakat sampai saat ini adalah adalah Sulamul Ibad, Nahwu Melayu, Tujuh kaifiyat, Manasik Haji, Mutiara Ramadhan dan Tuntunan Ziyarah Kubur. ${ }^{27}$

\section{Aplikasi Konsep Dakwah Dalam Bentuk Bi Al-hal.}

Terdapat empat bentuk pengembangan dakwah bi al-hal yang dikembangkan oleh ulamaulama Betawi, yaitu Mendirikan Majlis Ta'lim, Membangun Masjid atau mushalla, Pondok Pesantren dan Lembaga Pendidikan.

Sejak usia 17 tahun KH. Abdullah Syafi'ie sudah memperoleh Soerat Pemeberitahoean Pemerintah Hindia Belanda untuk mengajar di Langgar Partikulir. Pada tahun 1933 ketika umurnya 23 tahu kiyai mulai membangun Masjid Al-Barkah di Bali Matraman. Melalui Masjid kiyai mulai intens mengembangkan dakwah untuk masyarakat di sekitar masjid. Setiap sabtu pagi membuka pengajian kaum ibu yang dipimpin oleh istrinya Hj. Siti Ruqayah. Majlis ta'lim inilah yang kemudian dikembangkan oleh putrinya Prof. DR. Hj. Tuty Alawiyah menjadi Badan Kontak Majlis Ta'lim (BKMT). Dan setiap minggu pagi Kiyai membuka pengajian kaum bapak, yang sampai saat ini masih eksis diteruskan oleh putranya KH. Abdul Rasyid Abdullah Syafi'ie.

Melalui masjid dan pengembangan majlis ta'lim Al-Barkah kiyai mulai merintis pendirian lembaga pendidikan dan pondok pesantren. Pada tahun 1957 mulai membangun aula As Syafiiyah yang diperuntukkan bagi Madrasah Tsanawiyah Lilmuballighin wal Muallimin. Tahun 1965 mendirikan Akademi Pendidikan Islam As Syafiiyah (AKPI Asy Syafiiyah), yang pada tahun 1969 AKPI ditkembangkan menjadi Universitas Islam Asy Syafiiyah (UIA). Tahun 1968 merintis penddikan di Jati Waringin Pondok Gede. Tahun 1974-1975 mendirikan pesantren putra dan putri Asy Syafiiyah di Jatiwaringin. Dan pada tahun 1978 mulai membangun pesantren khusus anak yatim dan orang orang miskin. ${ }^{28}$

Prof. Dr. Murodi, MA menyatakan bahwa KH. Abdullah Syafi'ie adalah "Sosok Muallim Betawi Pengayom Dluafa”. ${ }^{29}$ Pernyataan ini menunjukkan bahwa KH. Abdullah Syafi'ie adalah sosok ulama yang sangat peduli terhadap penderitaan sesama dan sensitif terhadap persoalan sosial kemasyarakatan.

Aplikasi konsep dakwah dalam bentuk bi al-hal yang dilakukan oleh Buya KH. Abdurrahman Nawi adalah dengan mendirikan majlis ta'lim, pondok pesantren dan pemancar radio. Sebelum berdiri pesantren Al-Awwabin , terlebih dahulu Buya KH. Abdurrahman Nawi mendirikan majlis ta'lim. Berawal dari rumah pribadinya di Pengadegan Tebet Buya mendirikan majlis ta'lim as 
Salafiyah yang kemudian berkembang menjadi madrasah dan pondok pesantren Al-Awwabin. Hal ini sesuai dengan penjelasan KH. Ahmad Mukhtar putra Buya KH. Abdurrahman Nawi.

Sejarah awal pesantren adalah dari rumah pribadi Buya di Pengadegan Tebet, dari kebun tebu kemudian dijadikan bilik menginap beberapa orang yang ingin belajar. Semula majlis ta'limnya bernama As Salafiyah, karena terus berkembang, pada tahun 1976 Buya membuka cabang majlis talim di daerah tebet dan sekitar jakarta, di musholla mushola dan masjid masjid. Di Tahun tersebut, Buya mengajak jamaah dan keluarga mendirikan gedung madrasah dua lantai. Pembangunan tersebut selesai tahun 1979 diresmikan oleh KH. Idham Kholid dan mengganti As Salafiyah menjadi Al Awwabin. Al Awwabin Tebet terus berkembang sehingga tidak mampu menampung murid. Bersama pengurus Al Awwabin Buya mencari lahan untuk pembangunan lahan baru. Dengan izin Allah Buya mendapatkan lokasi di Depok di Pesantren Al Awwabin ini. Pada tahun 1982, pesantren Al-Awwabin Depok secara resmi dibuka oleh Mentri Agama ketika itu Munawir Sadzali. Begitulah riwayat singkat pesantren Al-Awwabin ini yang juga berawal dari Majlis Talim As Salafiyah. ${ }^{30}$

Sejak tahun 1994 pondok pesantren Al-Awwabin yang didirikan oleh Buya KH. Abdurrahman Nawi telah melebarkan sayap dengan mebuka cabang ke 2 di Jl. H. Sulaiman No. 12 Kelurahan Bedahan Kecamatan Sawangan Kota Depok. Mulai tahun 2002 pesantren yang di Bedahan dikhususkan untuk santri putri, dan saat ini telah mendirikan Radio Dakwah Al-Awwabin (Rida FM) pada gelombang 98,5 FM.

\section{Simpulan}

Konsep dakwah yang dikembangkan oleh ulama Betawi adalah konsep dakwah yang berlandaskan aqidah ahlu al-Sunah wa al-Jamaah, fiqihnya Imam Syafii dan tasawufnya Imam alGhazali. Materi yang disampaikan adalah aqidah, ibadah, akhlak dan sejarah. Media dakwah yang digunakan adalah visual dalam bentuk buku, kitab maupun tulisan yang dicopy kemudian dibagikan; audio seperti radio dan audio-visual yaitu televisis berbasis komunitas. Pengembangan Konsep dakwah oleh ulama-ulama Betawi telah membentuk masyarakat Betawi menjadi masyarakat yang relegius, egaliter dan multikultural. Masyarakat yang sangat menghormati ulama, kuat memegang aqidah ahlussunah wa al-jamaah dan kukuh menjalankan tradisi keagamaan seperti yasinan, tahlilan, sholawatan, ratiban dan khataman.

Berdasarkan teori jaringan ulama Azyumardi Azra yang menjelaskan adanya konektivitas ulama Nusantara dan ulama Timur tengah abad XVII dan XVIII dan teori genealogi ulama Betawi Rakhmad Zailani Kiki yang menjelaskan bahwa, sebagaimana ulama nusantara yang terkoneksi dengan ulama Timur Tengah, hal yang sama juga berlaku atas ulama-ualama Betawi. Jaringan ulama Betawi memiliki enam poros utama yaitu Guru Manshur, Guru Marzuki, Guru Mughni, Guru Madjid, Guru Khalid dan Guru Mahmud Romli. Keenam poros utama ulama Betawi ini tersambung kepada Syaikh Mujtaba dan Syaikh Junaid al-Batawi yang selanjutnya terhubung dengan ulama-ulama Timur Tengah. Keenam poros utama ulama Betawi ini melahirkan ulamaulama ternama di tanah Betawi. Guru Manshur melahirkan Muallim Rojiun, KH. Muhajirin Amsar Ad-Dary, Muallim Rasyid dan KH. M. Syafi'i Hadzami.Guru Marzuki melahirkan KH. Muhammad Baqir, KH. Noer Ali, KH. Abdullah Syafi'ie, KH. Thohir Rohili dan lain lain. Guru Mughni melahirkan Guru Na’im dan KH. Mahrowi Abdussalam. Guru Madjid melahirkan KH. Najihun dan 
KH. Asirun. Guru Khalid melahirkan Guru Mujib dan Muallim Thabrani. Dan Guru Mahmud Romli melahirkan Guru Asmat dan KH. Fathullah Harun.

Guru Khalid melahirkan Guru Mujib dan Muallim Thabrani. Dan Guru Mahmud Romli melahirkan Guru Asmat dan KH. Fathullah Harun. Aplikasi Konsep Dakwah Ulama Betawi direalisasikan dalam bentuk bi al-lisan, bi al-qalam dan bi al-hal. Secara bi al-lisan ulama Betawi aktif sebagai penceramah di tengah masyarakat, mengisi pengajian rutin di majlis talim dan berdakwah lewat radio dan televisi. Secara bi al-qalam ulama Betawi banyak menghasilkan karya tulis baik kitab kuning maupun buku. Dan secara bi al-hal ulama Betawi mewujudkannya dengan mendirikan masjid, majlis talim, pondok pesantren, pesantren yatim dan dluafa, mendirikan radio dakwah dan televisi berbasis komunitas.

\section{Catatan Kaki}

${ }^{1}$ Murodi, Dakwah Dan Dialektika Kebudayaan Sejarah, Budaya dan Dakwah Islam Kontemporer, Jakarta: UIN Jakarta Press, 2004. Hal. 138.

2 Ridwan Saidi, Babad Tanah Betawi, Jakarta: PT. Gria Media Prima, 2002. Cet. 1, Hal. 143

3 H.M. Bibit Suprapto, Ensiklopedia Ulama Nusantara, Jakarta: Gelegar Media Indonesia, 2009. Hal. 73

4 Tuty Alawiyah, KH. Abdullah Syafïe: Membangun Bangsa Melalui Dakwah, Pendidikan, dan Sosial,

Jakarta: As-Syafiiyah, 2010. Hal. 27

5Jakartapedia.bpadjakarta.net/index.php/KH-Abdurrahman-Nawi ,Diakses pada tanggal 26 September 2016 pukul 23.00 WIB

${ }^{6}$ Hasil Wawancara dengan KH. Akhmad Mukhtar di Pondok Pesantren Al Awwabin Sawangan Depok pada tanggal 17 September 2016.

7 M. Republika.co.id/berita/koran/dialog-jumat/16/o2/26/sentra-intelektual-ulama-betawi, Diakses pada tanggal 26 Oktober 2016, Pukul 21.27

8 Azyumardi Azra Dalam Kata Pengantar pada Akhmad zailani Kiki, Genealogi Intelektual Ulama Betawi , Jakarta: Jakarta Islamic Centre, 2011, hal. 14

9 Murodi, Dakwah Dan Dialektika, Hal. 113

${ }^{10}$ Murodi, Dakwah Dan Dialektika, Hal. 113

${ }^{11}$ Rakhmad Zailani Kiki, Genealogi Inteletual Ulama Betawi Melacak Jaringan Ulama Betawi dari Awal Abad ke-19 Sampai Abad ke-21, Jakarta: Jakarta Islamic Centre, 2011. Hal. 65

${ }^{12}$ Rakhmad Zailani, Genealogi Intelektual Ulama., Hal. 86

${ }^{13}$ Rakhmad Zailani, Genealogi Intelektual Ulama., Hal. 91

14 Rakhmad Zailani, Genealogi Intelektual Ulama., Hal. 127

15 Rakhmad Zailani, Genealogi Intelektual Ulama., Hal. 143

${ }^{16}$ Rakhmad Zailani, Genealogi Intelektual Ulama., Hal. 151

17 Rakhmad Zailani, Genealogi Intelektual Ulama., Hal 156

${ }^{18}$ www.jakarta.go.id/v2/dbbetawi/detail/28/Abdullah-Syafii, Diakses pada tamggal 26 Oktober 2016 Pukul 09.47

19 Rakhmad Zailani Kiki, Genealogi Intelektual Ulama Betawi., Hal. 104

${ }^{20}$ Dokumentasi berupa pamflet tentang biografi singkat KH. Abdullah Syafi'ie

${ }^{21}$ Wawancara langsun denga KH. Ahmad Muhtar di Pesantren Al Awwabin Depok pada hari Sabtu Tanggal 17 September 2016

${ }^{22}$ Dokumentasi Kliping Surat Kabar yang memberitakan Wafatnya KH. Abdullah Syafi’ie 3 September 1985

${ }^{23}$ Jakartapedia.bpadjakarta.net/index.php/KH_Abdurrahman_Nawi, diakses pada tanggal 27 Oktober 2016 pukul 10.50

24 Wawancara langsung dengan KH. Ahmad Muhtar di Pesantren Al awwabin Depok Pada hari Sabtu 17 September 2016

${ }_{25}$ Tuty Alawiyah, Kepemimpinan Dakwah dan Keteladanan KH. Abdullah Syafi-ie, Hal. 8

${ }^{26}$ www.jakarta.go.id/v2/dbbetawi/detail/28/Abdullah-Syafii, Diakses pada tanggal 27 Oktober 2016 Pukul 1056

${ }_{27}$ Wawancara langsung dengan KH. Ahmad Muhtar di Pesantren Al awwabin Depok pada hari Sabtu 17 September 2016.

${ }_{28}$ Dokumentasi Pamflet Biografi Singkat KH. Abdullah Syafi'ie 
29 Murodi, Dakwah Dan Dialektika Kebudayaan Sejarah, Budaya, dan Dakwah Islam Kontemporer, Jakarta: UIN Press, 2014, Hal. 111

$3^{30}$ Wawancara Langsung Dengan KH. Ahmad Muhtar di Pondok Pesantren Al-Awwabin Depok pada hari Sabtu tanggal 17 September 2016 